\title{
HUBUNGAN ANTARA STATUS GIZI AWAL DENGAN STATUS PULANG DAN LAMA RAWAT INAP PASIEN DEWASA DI RUMAH SAKIT
}

\author{
Nurul Huda Syamsiatun ${ }^{1}$ Hamam Hadi² Madarina Julia ${ }^{3}$
}

\begin{abstract}
Background: Hospital malnutrition is reported to be prevalent in Indonesia. Wether nutritional status at admission is associated with nutritional status at discharge and length of stay remains unclear.

Objective: To assess the association between nutritional status at the admission and nutritional status at discharge and length of stay in adult hospitalized patients.

Methods: A total subjects of 293 adult patients who were admitted to internal and neurology departments of Dr. Sardjito, Dr.M.Jamil, and Sanglah hospitals were included in this study. Nutritional status of each patient was assessed using Body Mass Index (BMI) measured at admission and on discharge. Information on length of stay and hospital charge was collected based on medical records.

Results: Low energy intake was associated with worse outcome (OR 1,2 95\% Cl 1,74-11,94). Non infection diseases were also found to be associated with worse outcome (OR 6,91 95\% Cl 4,03-11,85) and length of stay (OR 1,83 95\% Cl 1,10-3,05). Prehospitalized and class of hospitalized were associated with length of stay (OR 2,34 95\% Cl 1,36-8,57).

Conclusion: Low nutritional status on admission and low energy intake were associated with higher risk of worse outcome (OR 2,34 95\% Cl 1,05-5,24) and (OR 3,41 95\% Cl $1,36-8,57)$.
\end{abstract}

Key words: length of stay, discharge status, nutritional status at the admission

\section{PENDAHULUAN}

Sebanyak $46 \%$ pasien yang dirawat di rumah sakit menderita malnutrisi (3). Malnutrisi pada pasien yang dirawat berhubungan dengan meningkatnya lama hari rawat inap, biaya, dan komplikasi $(1,2,3$, 4). Masalah gizi di rumah sakit sering diabaikan antara lain karena kurangnya dokumentasi berat badan, tinggi badan, dan asupan makanan. Monitor laboratorium untuk menilai status gizi sering tidak dilakukan, sedangkan pertambahan kebutuhan gizi pada keadaan sakit, trauma, stres, dan sebagainya sering diabaikan (5).

Pengkajian (asesmen) terhadap status gizi awal

Jurusan Gizi, Poltekes Yogyakarta

Magister Gizi dan Kesehatan, Pascasarjana UGM Yogyakarta

Bagian Anak RS Dr. Sardjito Yogyakarta masuk rumah sakit merupakan sistem peringatan dini untuk mengidentifikasi pasien risiko tinggi dan memerlukan intervensi gizi (2). Tujuan penelitian ini adalah mencari hubungan antara status gizi awal dengan status pulang dan lama rawat inap pasien dewasa serta faktor-faktor lain yang dapat mempengaruhi status pulang dan lama rawat pasien.

\section{BAHAN DAN METODE}

Penelitian ini menggunakan rancangan studi kohor prospektif dengan status gizi kurang (Indeks Massa Tubuh<18) saat pasien awal masuk rumah sakit sebagai kelompok terpapar (exposed) dan status gizi baik (IMT•18) pada saat awal masuk rumah sakit sebagai kelompok tidak terpapar (non exposed). Kedua kelompok kemudian di-follow up untuk dilihat status pulang (sembuh/tidak sembuh) dan lama rawat inapnya (Gambar 1).

Subjek penelitian adalah pasien berumur minimal 18 tahun, compos mentis, tidak mengalami tindakan bedah, dapat ditimbang, tidak mengalami edema, dan bersedia ikut serta dalam penelitian (dengan mengisi informed concent). Penelitian dilakukan di tiga rumah sakit, yaitu RS. Dr. M. Jamil Padang, RS. Dr. Sardjito Yogyakarta, dan RS. Sanglah Bali pada bangsal penyakit dalam dan bangsal penyakit saraf. Pelaksanaannya pada bulan Oktober 2002 sampai dengan Februari 2003.

Data antropometri diperoleh pada saat awal masuk (48 jam pertama subjek dirawat), sedangkan data asupan makan dilakukan setiap hari selama perawatan yang diperoleh dengan metode visual comstock untuk asupan makan dari rumah sakit dan metode recall 24 jam untuk asupan makan dari luar rumah sakit. Tenaga pengumpul data adalah lulusan D III gizi yang telah dilatih mengenai cara pengumpulan data pada penelitian ini. Data asupan makan dianalisis menggunakan program FP2. Data hubungan antarvariabel menggunakan analisis bivariat (chi square), kemudian dibandingkan risiko relatif antara 
kelompok terpapar dengan kelompok tidak terpapar. Sedangkan hubungan antara status gizi awal dan asupan energi dengan lama rawat inap dan status pulang menggunakan analisis stratifikasi (regresi logistik) dengan program Stata versi 6 dan SPSS versi 10.

\section{HASIL DAN BAHASAN}

\section{Gambaran Umum Rumah Sakit}

Ketiga rumah sakit yang digunakan sebagai lokasi penelitian merupakan rumah sakit rujukan dan rumah sakit pendidikan. Rumah Sakit Dr. M. Jamil Padang sebagai pusat rujukan untuk wilayah Sumatera Bagian Tengah, yaitu Jambi, Riau dan Bengkulu. Rumah Sakit Dr. Sardjito Yogyakarta merupakan pusat rujukan untuk wilayah D.I. Yogyakarta dan Jawa Tengah bagian selatan. Sedangkan RS Sanglah Bali merupakan pusat rujukan untuk wilayah regional Bali, NTB dan NTT.

\section{Karakteristik Subjek}

Subjek penelitian selama bulan Oktober 2002 sampai dengan Februari 2003 diperoleh 318 orang, namun pada perjalanan penelitian, terdapat subjek yang pulang atas permintaan sendiri, pindah bangsal, dan mengalami tindakan bedah. Sehingga diperoeh subjek penelitian sebanyak 293 orang yang dirawat di bangsal penyakit dalam dan bangsal penyakit saraf. Kelompok terpapar sebanyak 69 orang, sedangkan kelompok tidak terpapar sebanyak 224 orang. Penentuan sampel penelitian dilakukan secara proporsional masing-masing rumah sakit dan bangsal perawatan berdasarkan data pasien tiga bulan terakhir (bulan Juli sampai September 2002). Karakteristik subjek antara kelompok terpapar dan tidak terpapar dapat dilihat pada Tabel 1.

\section{Status Pulang}

Status pulang subjek dalam penelitian ini dibedakan menjadi dua yaitu status pulang sembuh dan tidak sembuh. Tabel 2 menunjukkan IMT bukan merupakan faktor risiko status pulang subjek dengan OR 1,02 (CI 0,58-1,80), demikian pula dengan LILA. Variabel antara yang tidak dapat diabaikan di antara status gizi awal dengan status pulang maupun lama rawat inap yaitu asupan energi.

Status gizi dibedakan menjadi 2 , yaitu kurang dan cukup. Berdasarkan Tabel 3, terlihat bahwa pasien yang pada awal masuk mempunyai status gizi kurang menurut IMT dan selama perawatan asupan energinya juga kurang, mempunyai risiko 3,05 kali lebih besar untuk pulang dalam keadaan tidak sembuh.

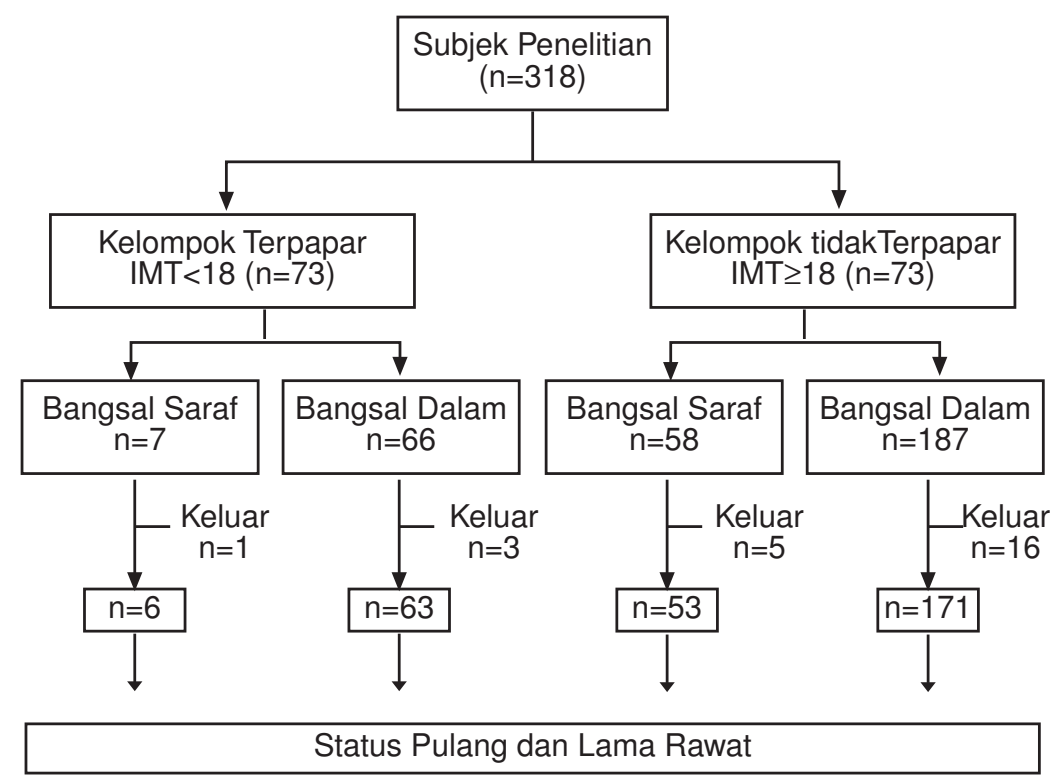

Gambar 1. Profil Penelitian 
Tabel 1. Karakteristik Subjek Penelitian

Berdasarkan Kelompok Terpapar dan Kelompok Tidak Terpapar

\begin{tabular}{|c|c|c|c|c|c|c|}
\hline \multicolumn{2}{|r|}{ Variabel } & \multirow{2}{*}{$\begin{array}{c}\mathrm{IMT}<18 \\
(\mathrm{n}=69) \\
\mathrm{n}(\%)\end{array}$} & \multirow{2}{*}{$\begin{array}{c}\mathrm{IMT} \cdot 18 \\
(\mathrm{n}=224) \\
\mathrm{n}(\%)\end{array}$} & \multirow[t]{2}{*}{$n(\%)$} & \multirow[t]{2}{*}{$x+$} & \multirow[t]{2}{*}{$\mathbf{p}$} \\
\hline & & & & & & \\
\hline 1. & $\begin{array}{l}\text { Penyakit utama } \\
-\quad \text { Infeksi } \\
-\quad \text { Non Infeksi }\end{array}$ & $\begin{array}{l}36(52,2 \%) \\
33(47,8 \%)\end{array}$ & $\begin{array}{l}95(42,4 \%) \\
129(37,6 \%)\end{array}$ & $\begin{array}{l}131(44,7) \\
162(55,3)\end{array}$ & 2,03 & 0,15 \\
\hline 2. & $\begin{array}{l}\text { Lama Prarawat } \\
-\quad \cdot 7 \text { hari } \\
-\quad<7 \text { hari }\end{array}$ & $\begin{array}{l}14(20,3 \%) \\
55(79,7 \%)\end{array}$ & $\begin{array}{l}36(16 \%) \\
188(84 \%)\end{array}$ & $\begin{array}{l}50(17,0) \\
243(83,0)\end{array}$ & 0,66 & 0,14 \\
\hline 3. & $\begin{array}{ll}\text { Asal RS } \\
\text { - } & \text { RS M. Jamil } \\
- & \text { RS Sardjito } \\
- & \text { RS Sanglah }\end{array}$ & $\begin{array}{l}20(29 \%) \\
21(30,4 \%) \\
28(59,4 \%)\end{array}$ & $\begin{array}{l}66(29,5 \%) \\
50(22,3 \%) \\
108(49,2 \%)\end{array}$ & $\begin{array}{l}86(38,4) \\
71(31,7) \\
136(29,9)\end{array}$ & 2,09 & 0,35 \\
\hline 4. & $\begin{array}{l}\text { Ruang Rawat } \\
\text { - } \quad \text { Peny. Dalam } \\
\text { - } \quad \text { Saraf }\end{array}$ & $\begin{array}{l}63(91,3 \%) \\
6(8,7 \%)\end{array}$ & $\begin{array}{l}171(76,3 \%) \\
53(23,7 \%)\end{array}$ & $\begin{array}{l}234(79,0) \\
59(21,0)\end{array}$ & 7,35 & $0,007^{*}$ \\
\hline 5. & $\begin{array}{l}\text { Kelas Perawatan } \\
-\quad \text { Kelas } 1 \\
-\quad \text { Kelas } 2 \& 3\end{array}$ & $\begin{array}{l}3(4,3 \%) \\
66(95,7 \%)\end{array}$ & $\begin{array}{l}17(7,6 \%) \\
207(92,4 \%)\end{array}$ & $\begin{array}{l}20(6,8) \\
273(93,2)\end{array}$ & - & $0,43^{* *}$ \\
\hline 6. & $\begin{array}{l}\text { Tempat Prarawat } \\
-\quad \text { Langsung RS } \\
-\quad \text { Rumah/yankes lain }\end{array}$ & $\begin{array}{l}39(56,5 \%) \\
30(43,5 \%)\end{array}$ & $\begin{array}{l}143(63,8 \%) \\
81(36,2 \%)\end{array}$ & $\begin{array}{l}182(62,1) \\
111(37,9)\end{array}$ & 1,20 & 0,27 \\
\hline
\end{tabular}

\section{Lama Rawat Inap}

Lama rawat inap dikategorikan menjadi 2 yaitu kurang dari 7 hari dan lebih atau sama dengan 7 hari. Berdasarkan Tabel 4, status gizi awal menurut IMT maupun LILA bukan merupakan faktor risiko yang mempengaruhi lama rawat inap secara langsung, namun berdasarkan analisis bivariat terdapat faktorfaktor lain yang mempengaruhi lama rawat inap pasien (Tabel 5).

Lama prarawat mempengaruhi lama rawat pasien di rumah sakit, subjek dengan lama prarawat 7 hari akan mempunyai risiko 2,34 kali untuk dirawat lebih lama di rumah sakit. Risiko subjek yang dirawat di kelas II dan III lebih besar 3,41 kali untuk dirawat lebih lama di rumah sakit dibandingkan dengan subjek di kelas perawatan I.
Antara status gizi awal dengan lama rawat terdapat variabel antara yang tidak dapat diabaikan yaitu asupan energi. Hasil analisis stratifikasi hubungan status gizi awal dan asupan energi dengan lama rawat dapat dilihat pada Tabel 6. Status gizi kurang dan asupan bukan merupakan faktor risiko yang mempengaruhi lama rawat pasien.

\section{Hubungan Status Gizi Awal dengan Status Pulang}

Berdasarkan Tabel 3 terlihat bahwa pasien yang mempunyai status gizi kurang pada awal masuk dan asupan energinya kurang selama dirawat inap di rumah sakit, maka kemungkinan pulang dalam keadaan tidak sembuh lebih besar 3,5 kali dibanding pulang dalam

Tabel 2. Hubungan Status Pulang dengan Status Gizi Awal

\begin{tabular}{|c|c|c|c|c|c|c|}
\hline \multicolumn{2}{|r|}{ Status Gizi } & \multicolumn{2}{|c|}{ Status Pulang } & \multirow{2}{*}{$\begin{array}{c}\text { Jumlah } \\
\text { n(\%) }\end{array}$} & \multirow[t]{2}{*}{ OR } & \multirow[t]{2}{*}{$(95 \%) \mathrm{Cl}$} \\
\hline & & $\begin{array}{c}\text { Tidak sembuh } \\
\text { n(\%) }\end{array}$ & $\begin{array}{c}\text { Sembuh } \\
\text { n (\%) }\end{array}$ & & & \\
\hline \multicolumn{7}{|c|}{ 1. IMT } \\
\hline & $-<18$ & $45(65,22)$ & $24(34,78)$ & $69(100)$ & 1,02 & $0,58-1,80$ \\
\hline & $-\cdot 18$ & $145(64,73)$ & $79(35,27)$ & $224(100)$ & & \\
\hline \multicolumn{7}{|c|}{ 2. LILA } \\
\hline & $-\quad<22,6$ & $49(67,12)$ & $24(32,88)$ & $73(100)$ & 1,15 & $0,65-2,01$ \\
\hline & $-\quad \cdot 22,6$ & $141(64,10)$ & $79(36,90)$ & $220(100)$ & & \\
\hline
\end{tabular}


keadaan sembuh. Sedangkan pasien dengan status gizi awal baik tetapi asupan energinya kurang selama perawatan akan mempunyai risiko yang lebih tinggi dibandingkan status gizi awal kurang namun asupan energinya cukup selama perawatan. Dengan demikian, jelas bahwa asupan energi selama perawatan mempengaruhi tingkat kesembuhan pasien di rumah
Ketepatan intervensi gizi yang diberikan akan meningkatkan indikator klinis dan biokimia yang selanjutnya akan menurunkan risiko komplikasi, akhirnya meningkatkan kesembuhan (8). Pemberian nutrisi yang tidak adekuat mengakibatkan keadaan kurang gizi yang dapat meningkatkan morbiditas dan mortalitas (9).

Pasien dengan status gizi awal baik mempunyai

Tabel 3. Analisis Stratifikasi Status Gizi Awal dan Asupan Energi selama Perawatan terhadap Rasio Odds Status Pulang Tidak Sembuh

\begin{tabular}{|c|c|c|c|c|c|c|}
\hline \multirow{2}{*}{\multicolumn{2}{|c|}{ Status Gizi Awal }} & \multirow{2}{*}{$\begin{array}{c}\text { Asupan } \\
\text { Energi }\end{array}$} & \multirow[t]{2}{*}{ Jumlah } & \multicolumn{3}{|c|}{ Status Pulang } \\
\hline & & & & OR & $p$ & $\mathrm{Cl}(95 \%)$ \\
\hline \multicolumn{7}{|c|}{ 1. IMT } \\
\hline & - Baik & - Cukup & 80 & 1,0 & & \\
\hline & - Baik & - Kurang & 65 & 1,73 & 0,16 & $0,84-3,71$ \\
\hline & - Kurang & - Cukup & 30 & 1,47 & 0,41 & $0,06-3,70$ \\
\hline & - Kurang & - Kurang & 15 & 3,51 & 0,03 & $1,10-11,2^{*}$ \\
\hline \multicolumn{7}{|c|}{ 2. LILA } \\
\hline & - Baik & - Cukup & 79 & 1,0 & & \\
\hline & - Baik & - Kurang & 62 & 2,03 & 0,06 & $0,96-4,33$ \\
\hline & - Kurang & - Cukup & 31 & 2,30 & 0,09 & $0,87-5,6$ \\
\hline . & - Kurang & - Kurang & 18 & 3,05 & 0,04 & $1,03-9,04^{*}$ \\
\hline
\end{tabular}

Keterangan : *) signifikan $(p<0,05)$

sakit. Hal ini didukung oleh berbagai teori dan hasil penelitian yang akan dikemukakan di bawah ini. Pada keadaan lapar, simpanan glikogen akan digunakan dengan cepat untuk menghasilkan energi. Agar dapat memenuhi kebutuhan glukosa yang meningkat, maka terjadi proses glukoneogenesis sehingga proses katabolisme tubuh dapat dikendalikan. Dengan demikian maka asupan makan yang adekuat perlu diberikan (6).

Pemenuhan makanan atau zat gizi yang cukup akan memegang peranan penting dalam proses penyembuhan dan memperpendek lama rawat inap (7). kemungkinan lebih besar pulang dalam keadaan sembuh dibanding status gizi kurang walaupun secara statistik tidak bermakna. Status gizi kategori kurang mengakibatkan penurunan daya tahan tubuh terhadap penyakit sehingga pasien mudah terkena komplikasi dan infeksi yang berakibat memperlama proses penyembuhan dan lama rawat inap. Hal ini antara lain didukung oleh Rackow (10) yang menyatakan bahwa status gizi yang baik pada pasien rawat inap dapat meningkatkan respon pasien terhadap terapi yang dilakukan, menurunkan insiden infeksi, komplikasi, dan mempersingkat waktu pemulihan

Tabel 4. Hubungan Status Gizi Awal dengan Lama Rawat Inap

\begin{tabular}{|c|c|c|c|c|c|c|}
\hline \multicolumn{2}{|c|}{ Variabel } & \multicolumn{2}{|c|}{ Lama Rawat Inap } & \multirow[t]{2}{*}{ Jumlah } & \multirow[t]{2}{*}{ OR } & \multirow[t]{2}{*}{$\mathrm{Cl}(95 \%)$} \\
\hline & & $\begin{array}{c}\text { - } 7 \text { hari } \\
\text { n (\%) }\end{array}$ & $\begin{array}{c}<7 \text { hari } \\
\text { n (\%) }\end{array}$ & & & \\
\hline 1. & $\begin{array}{l}\text { IMT } \\
\begin{array}{l}\text { IMT } \\
-\quad 18 \\
-\quad 18\end{array}\end{array}$ & $\begin{array}{r}53(76,8) \\
157(70,0)\end{array}$ & $\begin{array}{l}16(23,2) \\
67(30)\end{array}$ & $\begin{array}{r}69(100 \%) \\
224(100 \%)\end{array}$ & $\begin{array}{c}1,41 \\
1\end{array}$ & $0,75-2,65$ \\
\hline 2. & $\begin{array}{l}\text { LILA } \\
-\quad<22,6 \\
-\quad \cdot 22,6\end{array}$ & $\begin{array}{r}54(73,9) \\
156(70,9)\end{array}$ & $\begin{array}{r}19(26,1) \\
64(29,1)\end{array}$ & $\begin{array}{r}73(100 \%) \\
220(100 \%)\end{array}$ & $\begin{array}{l}1,16 \\
1\end{array}$ & $0,64-2,12$ \\
\hline
\end{tabular}


setelah sakit.

Pasien dengan status gizi awal kurang berdasarkan Subjective Global Asessment (SGA) mempunyai risiko terjadi komplikasi dan infeksi lebih besar dibanding pasien dengan status gizi baik (4). Pasien anak yang status gizinya baik (non underweight) pada saat masuk mempunyai kemungkinan pulang dalam keadaan sembuh 1,46 kali dan kemungkinan pulang dalam keadaan tidak meninggal kanker, DM, jantung, penyakit saraf, dan anemia. Sebagian besar dari penyakit-penyakit tersebut adalah penyakit kronis dan sulit disembuhkan, sedangkan terapi gizi maupun terapi lainnya hanya bersifat paliatif saja bukan untuk penyembuhan. Pasien dengan penyakit noninfeksi yang dirawat inap mempunyai kemungkinan lebih besar untuk pulang dalam keadaan malnutrisi (14).

Tabel 5. Analisis Bivariat Faktor-Faktor yang Berhubungan dengan Lama Rawat Inap

\begin{tabular}{|c|c|c|c|c|c|c|}
\hline \multicolumn{2}{|c|}{ Variabel } & \multicolumn{2}{|c|}{ Lama Rawat } & \multirow[t]{2}{*}{ Jumlah } & \multirow[t]{2}{*}{ OR } & \multirow[t]{2}{*}{$\mathrm{Cl}(95 \%)$} \\
\hline & & $\begin{array}{c}\text {-7 hari } \\
\text { n (\%) }\end{array}$ & $\begin{array}{c}<7 \text { hari } \\
\text { n (\%) }\end{array}$ & & & \\
\hline 1. & $\begin{array}{l}\text { Asupan energi } \\
\quad<75 \% \\
\cdot 75 \%\end{array}$ & $\begin{array}{r}124(59) \\
86(41)\end{array}$ & $\begin{array}{l}41(49,4) \\
42(50,6)\end{array}$ & $\begin{array}{l}165(100 \%) \\
128(100 \%)\end{array}$ & $\begin{array}{c}0,70 \\
1\end{array}$ & $0,41-1,13$ \\
\hline 2. & $\begin{array}{l}\text { Penyakit } \\
\text { Infeksi } \\
\text { Non Infeksi }\end{array}$ & $\begin{array}{c}85(64,9) \\
125(77,2)\end{array}$ & $\begin{array}{l}46(35,1) \\
37(22,8)\end{array}$ & $\begin{array}{l}131(100 \%) \\
162(100 \%)\end{array}$ & $\begin{array}{c}1,83 \\
1\end{array}$ & $1,10-3,05^{*}$ \\
\hline 3. & $\begin{array}{l}\text { Lama Prarawat } \\
\quad>=7 \text { hari } \\
\quad<7 \text { hari }\end{array}$ & $\begin{array}{r}42(84,0) \\
168(69,1)\end{array}$ & $\begin{array}{c}8(16) \\
75(30,9)\end{array}$ & $\begin{array}{r}50(100 \%) \\
243(100 \%)\end{array}$ & $\begin{array}{c}2,34 \\
1\end{array}$ & $1,05-5,24^{*}$ \\
\hline 4. & $\begin{array}{l}\text { Tempat Prarawat } \\
\text { Langsung RS } \\
\text { Rumah/ Yankes lain }\end{array}$ & $\begin{array}{c}127(69,8) \\
83(74,8)\end{array}$ & $\begin{array}{l}55(30,2) \\
28(25,2)\end{array}$ & $\begin{array}{l}182(100 \%) \\
111(100 \%)\end{array}$ & $\begin{array}{c}1,30 \\
1\end{array}$ & $0,75-2,19$ \\
\hline 5. & $\begin{array}{l}\text { Kelas Perawatan } \\
\text { Kelas } 1 \\
\text { Kelas } 2 \text { \& } 3\end{array}$ & $\begin{array}{r}9(45,0) \\
201(73,6)\end{array}$ & $\begin{array}{l}11(55,0) \\
72(26,4)\end{array}$ & $\begin{array}{r}20(100 \%) \\
273(100 \%)\end{array}$ & $\begin{array}{c}3,41 \\
1\end{array}$ & $1,36-8,57^{*}$ \\
\hline
\end{tabular}

2,08 kali lebih tinggi dibandingkan pasien underweight (11). Kemungkinan besar, pasien dengan status gizi kategori kurang masih memerlukan fasilitas perawatan di rumah dibandingkan pasien dengan status gizi baik (3).

Pasien malnutrisi akan mengalami perubahan organ terutama limfoid, pengurangan proliferasi limfosit, penurunan angka limfosit, penurunan sel T, dan interferon gamma yang akan menyebabkan menurunnya imunitas tubuh, sehingga kemampuan untuk melawan penyakit menurun (12). Asupan makanan dapat pula dipengaruhi oleh penyakit yang diderita. Penyakit yang diderita dapat mempengaruhi penerimaan makanan yang berdampak pada asupan zat gizi seseorang(13).

Penyakit noninfeksi pada penelitian ini antara lain

\section{Hubungan Status Gizi Awal dengan Lama Rawat Inap}

Hasil analisis stratifikasi antara status gizi awal dan asupan energi terhadap lama rawat terlihat bahwa subyek dengan status gizi awal kategori kurang dengan asupan makanan kategori kurang, bukan merupakan faktor risiko yang berhubungan langsung dengan lama rawat. Hal ini menunjukkan bahwa lama rawat tidak dipengaruhi oleh status gizi awal dan asupan makan, namun ada faktor lain yang lebih berperan yaitu penyakit yang diderita.

Hasil analisis bivariat antara faktor-faktor yang berpengaruh terhadap lama rawat secara signifikan antara lain: jenis penyakit, lama prarawat, dan kelas perawatan. Hal ini didukung oleh Tomkins (15) yang menyatakan bahwa penyakit infeksi maupun 
noninfeksi mempunyai faktor risiko untuk menjadi gizi baik, gizi kurang, bahkan gizi buruk, tergantung dari sifat perjalanan penyakit tersebut, yaitu kronis atau akut, yang akan berpengaruh pada lama rawat inapnya.

Penyakit noninfeksi mempunyai risiko 1,8 kali lebih besar untuk dirawat inap lebih lama dibandingkan penyakit infeksi. Penyakit noninfeksi pada penelitian ini termasuk penyakit kronis yang proses penyembuhannya memerlukan waktu yang
Kelas perawatan mempunyai pengaruh terhadap lama rawat inap. Subjek yang dirawat di kelas 2 dan 3 mempunyai risiko 3,4 kali lebih besar untuk dirawat lebih lama dibanding subjek yang dirawat di kelas 1 . Dari hasil analisis krostabulasi ditemukan bahwa pasien yang dirawat di kelas 2 dan 3 mempunyai asupan kurang sebanyak $44,7 \%$, sedangkan pasien kelas 1 hanya $30 \%$ yang mempunyai asupan energi kurang. Kelas perawatan merupakan salah satu faktor non-gizi yang dapat dapat menyebabkan terjadinya

Tabel 6. Analisis Stratifikasi Status Gizi Awal dan Asupan Energi selama Perawatan terhadap Rasio Odds Lama Rawat $\bullet 7$ hari

\begin{tabular}{|c|c|c|c|c|c|c|}
\hline \multirow{2}{*}{\multicolumn{2}{|c|}{ Status Gizi Awal }} & \multirow[t]{2}{*}{ Asupan Energi } & \multirow[t]{2}{*}{ Jumlah } & \multicolumn{3}{|c|}{ Lama Rawat } \\
\hline & & & & OR & $\mathbf{p}$ & $\mathrm{Cl}(95 \%)$ \\
\hline \multicolumn{7}{|c|}{ 1. IMT } \\
\hline - & Baik & - Cukup & 87 & 1,0 & - & - \\
\hline & Baik & - Kurang & 70 & 0,9 & 0,83 & $0,48-1,78$ \\
\hline & Kurang & - Cukup & 37 & 1,6 & 0,29 & $0,67-3,76$ \\
\hline- & Kurang & - Kurang & 16 & 1,4 & 0,55 & $0,47-4,09$ \\
\hline \multicolumn{7}{|c|}{ 2. LILA } \\
\hline- & Baik & - Cukup & 90 & 1,0 & - & - \\
\hline- & Baik & - Kurang & 66 & 0,9 & 0,64 & $0,45-1,64$ \\
\hline - & Kurang & - Cukup & 34 & 1,3 & 0,60 & $0,54-2,90$ \\
\hline- & Kurang & - Kurang & 20 & 1,3 & 0,66 & $0,46-3,44$ \\
\hline
\end{tabular}

lebih lama. Kanker tergolong penyakit noninfeksi dan dapat menyebabkan efek yang merugikan terhadap status gizi. Efek dari pengobatan dan akibat fisiologis dari kanker dapat mengganggu dalam mempertahankan kecukupan gizi, sehingga menimbulkan penurunan berat badan yang berakibat pada penyembuhan dan lama rawat inap yang lebih lama (16).

Pasien dengan sianosis dan gagal jantung kongestif dengan komplikasinya dapat mengganggu asupan nutrisi dan dapat mempengaruhi tingginya frekuensi malnutrisi kronik (17). Lama prarawat sebelum masuk rumah sakit mempengaruhi lama rawat pasien di rumah sakit. Semakin lama subjek dirawat sebelum masuk rumah sakit maka mempunyai risiko 2,3 kali lebih besar untuk dirawat inap lebih lama.

Semakin lama seseorang dirawat inap di rumah sakit, maka akan semakin berpengaruh pada kondisi fisiologisnya. Semakin lama dirawat inap, seseorang akan mengalami atropi otot karena kurang bergerak. Atropi otot menyebabkan otot mengecil yang berarti menurun pula status gizi pasien, sehingga berpengaruh pada proses penyembuhan dan lama rawat inap. malnutrisi. Malnutrisi pada pasien di rumah sakit akan berakibat pada lamanya proses penyembuhan dan lama rawat itu sendiri (18). Kelas perawatan dapat mempengaruhi persepsi pasien terhadap makanan yang disajikan, sehingga berdampak pula pada penerimaan pasien terhadap makanan dan akhirnya mempengaruhi asupan makan pasien (13).

Kelas perawatan biasanya mempunyai perbedaan dalam hal pengaturan ruang, cara penyajian makanan, maupun fasilitas lainnya. Pasien yang dirawat di kelas 1 tidak banyak berinteraksi dengan pasien lain seperti halnya kelas 2 dan 3 , sehingga secara psikologis tidak terlalu terbebani, lebih merasa nyaman dan kemungkinan tertular penyakit lain lebih kecil, sehingga lebih membantu dalam mempercepat penyembuhan dan mempersingkat waktu rawat.

\section{KESIMPULAN DAN SARAN}

Berdasarkan hasil analisis dan uji statistik yang telah dilakukan dalam penelitian ini, maka dapat diambil kesimpulan sebagai berikut:1. Semakin baik status gizi awal saat masuk rumah sakit dan asupan energi yang cukup, mempunyai risiko terkecil untuk 
pulang dalam keadaan tidak sembuh, sebaliknya semakin kurang status gizi awal dan asupan energi selama perawatan maka mempunyai risiko untuk pulang dalam keadaan tidak sembuh lebih besar; 2 . Status gizi awal dan asupan energi selama perawatan tidak berpengaruh secara signifikan terhadap lama rawat inap pasien.

Berdasarkan kesimpulan tersebut penulis menyarankan: 1. Bagi institusi terkait (rumah sakit), diperlukan perhatian terhadap pasien dengan status gizi awal masuk rumah sakit berkategori kurang dengan upaya perbaikan status gizi melalui pemenuhan kebutuhan energi sebagai upaya untuk menentukan proses kesembuhan pasien. Sedangkan pada pasien dengan status gizi awal berkategori baik perlu dipertahankan; 2. Perubahan status gizi yang diukur menggunakan Indeks Massa Tubuh (IMT) dan Lingkar Lengan Atas (LILA) dapat membantu memonitor keberhasilan terapi gizi dan memprediksi outcome hospitalisasi.

\section{Ucapan Terima Kasih}

Penulis mengucapkan terima kasih kepada Direktur beserta staf RS Dr. Sardjito Yogyakarta, RS Dr. M. Jamil Padang, dan RS Sanglah Bali, para enumerator, serta semua pihak yang tidak dapat disebutkan satu per satu.

\section{RUJUKAN}

1. Robinson, G., Goldstein, M., and Levine, G. Impact of nutritional status on DRG length of stay. JPEN 1986;11:49-51.

2. Messner RL, Stephens, N., Wheeler, W.E, et al. Effect of admission nutritional status on length of hospital stay. Society of Gastroenterology Nurses and Associates 1991:202-5.

3. Chima C, Barco K, Dewitt M, et al. Relationship of nutritional status to length of stay, hospital cost, and discharge status of patients hospitalized in the medicine service. J Am Diet Assoc 1997:975-80.

4. Braunchweig C, Gomez S, and Sheean P. Impact of declines in nutritional status on outcomes in adult patients hospitalized for more than 7 days. J Am Diet Assoc 2000;100:1316-24.

5. Saifun S. Nutrisi klinik pada penyakit anak. Dalam Daldiyono \& Thaha, editors. Kapita Selekta Nutrisi Klinik. Jakarta: Pernepari; 1998.
6. Hill G. Disorders of nutrition and metabolism in clinical surgery: understanding and management, Darmawan I. Jakarta: Gramedia; 2000.

7. Departemen Kesehatan. Buku pedoman pelayanan gizi rumah sakit. Jakarta: Depkes RI; 1991.

8. Wyszynski D, Crivelli A, Esquerro S, et al. Assessment of nutritional status in a population of recently hospitalized patients. Medicina (B Aires) 1997;58:51-7.

9. Soegih Rachmad. Pola penanganan kasus gizi di Puskesmas dan rumah sakit. Dalam Daldiyono \& Thaha, editors. Kapita Selekta Nutrisi Klinik. Jakarta: Pernepari; 1998.

10. Rackow JR. Nutritional care of the patients in office practice. Hargerstown: Medical Dept. Harper \& Row Publication; 1981.

11. Majid N. Status gizi awal pasien anak rawat inap RSUP dr. Sardjito sebagai prediktor lama perawatan dan status pulang [thesis]. Yogyakarta: Pascasarjana Universitas Gadjah Mada; 2001.

12. Bradley $\mathrm{J}$ and $\mathrm{Xu}$, Xiaoning. Diet, age, and immune system. Nutr Rev 1996;54(11): 543-50.

13. Almatsier $S$, Jus'at I, \& Akmal N. Persepsi pasien terhadap makanan di rumah sakit (survey pada 10 rumah sakit di Jakarta). Gizi Indonesia 1992;17(12):87-96.

14. Wardhana, Wishnu. Pengaruh penyakit infeksi dan noninfeksi terhadap status pulang pasien anak di bangsal rawat inap [thesis] Yogyakarta: Pascasarjana Universitas Gadjah Mada; 2002.

15. Tomkins AM. Nutrition and infection in protein energy malnutrition. $2^{\text {nd. }}$ ed. Erward Arnold a Devision of Hodder and Spoughton; 1992.

16. Moore MC. 1993. Pocket guide to nutrition and diet therapy. $2^{\text {nd }}$ ed. Oswari L. Jakarta: Hipokrates; 1997.

17. Cameron JW, Rosenthal A, Olson AD. Malnutrition in hospitalized children with conginital heart disease. Arch Pediatr Adolesc Med 1995;149:1098-02.

18. Daldiyono \& Thaha AR. Kapita selekta nutrisi klinik. Jakarta: Pernepari; 1998. 
34 JURNAL GIZI KLINIK INDONESIA, Volume 1 No.1 Mei 2004 